\title{
Inoculum acclimation to oleate promotes the conversion of olive mill wastewater to methane
}

\author{
M.R. Gonçalves ${ }^{\mathrm{a}, \mathrm{b}, *}$, J.C. Costa $^{\mathrm{a}}$, I.P. Marques ${ }^{\mathrm{b}}$, M.M. Alves ${ }^{\mathrm{a}}$ \\ ${ }^{a}$ Institute for Biotechnology and Bioengineering (IBB), University of Minho, 4710057 Braga, Portugal \\ ${ }^{\mathrm{b}}$ Bioenergy Unit, National Laboratory of Energy and Geology I.P. (LNEG), Estrada Paço do Lumiar 22, 1649038 Lisboa, Portugal
}

\section{A R T I C L E I N F O}

\section{Article history:}

Received 10 September 2009

Received in revised form

16 April 2010

Accepted 24 April 2010

Available online 26 May 2010

\section{Keywords:}

Anaerobic digestion

Biodegradability

Biogas

Biomass selection

Lipids

Toxicity

\begin{abstract}
A B S T R A C T
This work aims at selecting a suitable strategy to accelerate the start-up of the anaerobic treatment of olive mill wastewater (OMW) and to enhance the biogas production. Two anaerobic sludges were tested in toxicity and biodegradability batch experiments: biomass acclimated to oleate (BAO) and biomass non-acclimated (BNA). The results showed that the resistance to OMW toxicity was higher for the BAO than for the BNA. In the presence of OMW, the BNA was inhibited at all concentrations tested, whereas for the BAO no inhibition occurred at 5 and $10 \mathrm{~g} \mathrm{COD} \mathrm{L}^{-1}$. In fact, even at $25 \mathrm{~g} \mathrm{COD} \mathrm{L}^{-1}$ both substrates (acetate + OMW) were degraded. The biodegradation rate of OMW was higher in batch vials with the acclimated sludge.

The results demonstrate that the use of an acclimated microbial consortium to LCFA compounds is a promising strategy to accelerate the start-up of the digestion process, and to improve the overall anaerobic treatment of a real oily wastewater such as OMW with simultaneous bioenergy production (biogas).
\end{abstract}

(c) 2010 Elsevier Ltd. All rights reserved.

\section{Introduction}

Olive mill wastewater (OMW) constitutes the major waste resulting from the traditional press mills and the continuous three phase mills of olive oil production [1]. The uncontrolled disposal of this wastewater constitutes a serious environmental pollution problem. Nowadays, OMW is still discharged directly into sewer systems and water streams or is concentrated in cesspools, despite the fact that such disposal methods are prohibited in many Mediterranean countries [2]. The main problem regarding the disposal of OMW is to find an environmental and economical viable solution [3].

Anaerobic digestion is a recognized option for the energetic valorization of these high strength wastewaters [4,5]. The biogas produced from OMW degradation can be utilized for CHP (combined heat and power) production and used as transport fuel $[6,7]$. Additionally, the treated water is an added value product for use in irrigation in countries with water shortages [8].

Olive oil campaign lasts 3-4 months and large quantities of wastewater are produced in that period. Conversely, there is no effluent during the rest of the year. Although the anaerobic reactors

\footnotetext{
* Corresponding author. Institute for Biotechnology and Bioengineering (IBB), University of Minho, 4710057 Braga, Portugal. Tel.: +351 253604400; fax: +351 253678986.

E-mail address: marta.goncalves@deb.uminho.pt (M.R. Gonçalves).
}

can advantageously restart after several months of shut-down, they have long periods of start-up and process stabilisation being one of the main drawbacks of those processes.

Reactor start-up is a very important economic process step, because during this period the production of the effluent must be adapted to the capacity of the wastewater treatment plant [9]. The start-up of anaerobic digesters has been described in literature as a critical step and one of the most difficult periods to control [10,11]. Different strategies have been reported to accelerate the start-up period and to improve the process efficiency and stability [9,11-14]. In the case of OMW treatment, the presence of inhibitory substances such as lipidic, namely long chain fatty acids (LCFA), and phenolic compounds gives higher periods of start-up and cause several operational problems. Fiestas Ros de Ursinos et al. (1982) obtained a very long start-up period during one year in attempting to treat undiluted olive mill effluent $\left(40-60 \mathrm{~g} \mathrm{COD} \mathrm{L}^{-1}\right)$ with unadapted inocula [15]. Recently, Azbar et al. (2009) carried out a start-up phase for 3 months with diluted olive mill effluent ( $5 \mathrm{~g}$ $\mathrm{COD} \mathrm{L}^{-1}$ ) and a hydraulic retention time (HRT) of 10 days, in order to adapt the sludge to the operation conditions [16]. It was suggested that the difficulty to start a digester on concentrated olive oil wastewater using unacclimated inocula is due to the environmental conditions (build up of volatile acids and inhibiting compounds) that are particularly unfavourable to the growth of methanogens [17]. 
Table 1

Main characteristics of olive mill wastewater used in the batch experiments.

\begin{tabular}{lr}
\hline Parameter & OMW \\
\hline $\mathrm{pH}$ & 4.7 \\
$\mathrm{COD}\left(\mathrm{g} \mathrm{L}^{-1}\right)$ & 115.0 \\
$\mathrm{TS}\left(\mathrm{g} \mathrm{L}^{-1}\right)$ & 124.6 \\
$\mathrm{VS}\left(\mathrm{g} \mathrm{L}^{-1}\right)$ & 58.4 \\
Total phenols $\left(\mathrm{g} \mathrm{L}^{-1}\right)$ & 7.7 \\
\hline
\end{tabular}

Hamdi studied the biodegradability and toxicity of OMW and concluded that the darkly coloured polyphenols induced the problem of OMW biodegradation, whereas the long chain fatty acids (LCFA), tannins, and simple phenolic compounds are responsible for its toxicity to methanogenic bacteria [18]. Lipids are attractive substrates for anaerobic digestion due to the higher methane yield obtained, when compared to proteins or carbohydrates. They are readily hydrolysed to long chain fatty acids from which oleic acid results as the major component. However, LCFA tend to accumulate onto the sludge and give rise to flotation and washout of biomass [19]. Beccari et al. performed batch experiments to evaluate the inhibitory effect of OMW on methanogenesis by using oleic acid as a model compound of lipids. They reported that the addition of $0.35 \mathrm{~g} \mathrm{~L}^{-1}$ of oleic acid to diluted OMW (5.7 g $\mathrm{COD} \mathrm{L}^{-1}$ ) exerted a strong inhibition effect since it doubled the methanogenesis lag phase. Furthermore, the addition of an easily biodegradable co-substrate neither increased the rate of substrate degradation nor the methane formation [20].

Recently, it was demonstrated that LCFA can be efficiently mineralized, in continuous, by an acclimated microbial consortium [21], despite the previously reported bacterial inhibition caused by LCFA [18-20].

Considering that the OMW production is concentrated in $3 / 4$ months per year, the selection of a suitable inoculum is essential to accelerate the anaerobic process start-up and to reduce the operational problems caused by the inhibitory compounds. In this work, an acclimated microbial consortium to oleate was used in batch experiments aiming to increase the tolerance of anaerobic digestion inoculum to the OMW toxicity and to enhance the conversion of OMW to methane.

\section{Material and methods}

\subsection{Batch experiments}

\subsubsection{Inoculum}

Toxicity and biodegradability batch experiments were performed using two different inocula: biomass acclimated to oleate (BAO) and Biomass non-acclimated (BNA). The sludge acclimated to oleate was obtained as described elsewhere [21]. The sludge nonacclimated was obtained from an upflow anaerobic sludge blanket (UASB) reactor. Both inocula were pre-incubated at $37^{\circ} \mathrm{C}$ in order to deplete the residual biodegradable organic material.

\subsubsection{Substrate}

OMW was obtained from a three phase continuous olive oil extraction process (Amarante, Portugal). The substrate was stored at $-20^{\circ} \mathrm{C}$ until being used. The effluent was characterized as described in the analytical methods section and the values obtained are summarized in Table 1 . Before using the substrate, $\mathrm{pH}$ was adjusted to $7.0-7.2$ with $\mathrm{NaOH} 8 \mathrm{~N}$.

\subsubsection{Batch assays: set up and procedure}

The working volume was $12.5 \mathrm{~mL}$. The sludge (final concentration around $2-5 \mathrm{~g} \mathrm{VSS} / \mathrm{L}$ ) was added to the vials. The basal medium used in all batch experiments was made up with demineralised water and sodium bicarbonate $\left(3 \mathrm{~g} \mathrm{~L}^{-1}\right)$, then the $\mathrm{pH}$ was adjusted to 7.0-7.2. In the methanogenic toxicity tests, the OMW concentration ranged from 5 to $50 \mathrm{~g} \mathrm{COD} \mathrm{L}^{-1}$. Acetate was added as co-substrate $(30 \mathrm{mM})$ in order to evaluate the influence of OMW concentration on the acetoclastic activity. Biodegradability tests were performed with OMW concentrations of 5 and $10 \mathrm{~g} \mathrm{COD} \mathrm{L}^{-1}$. The headspace of the batch vials was flushed with $\mathrm{N}_{2} / \mathrm{CO}_{2}$ $(80: 20 \mathrm{v} / \mathrm{v})$. Before incubation, the vials were reduced with $\mathrm{Na}_{2} \mathrm{~S} .9 \mathrm{H}_{2} \mathrm{O}$ to a final concentration of $1 \mathrm{mM}$. All batch tests were
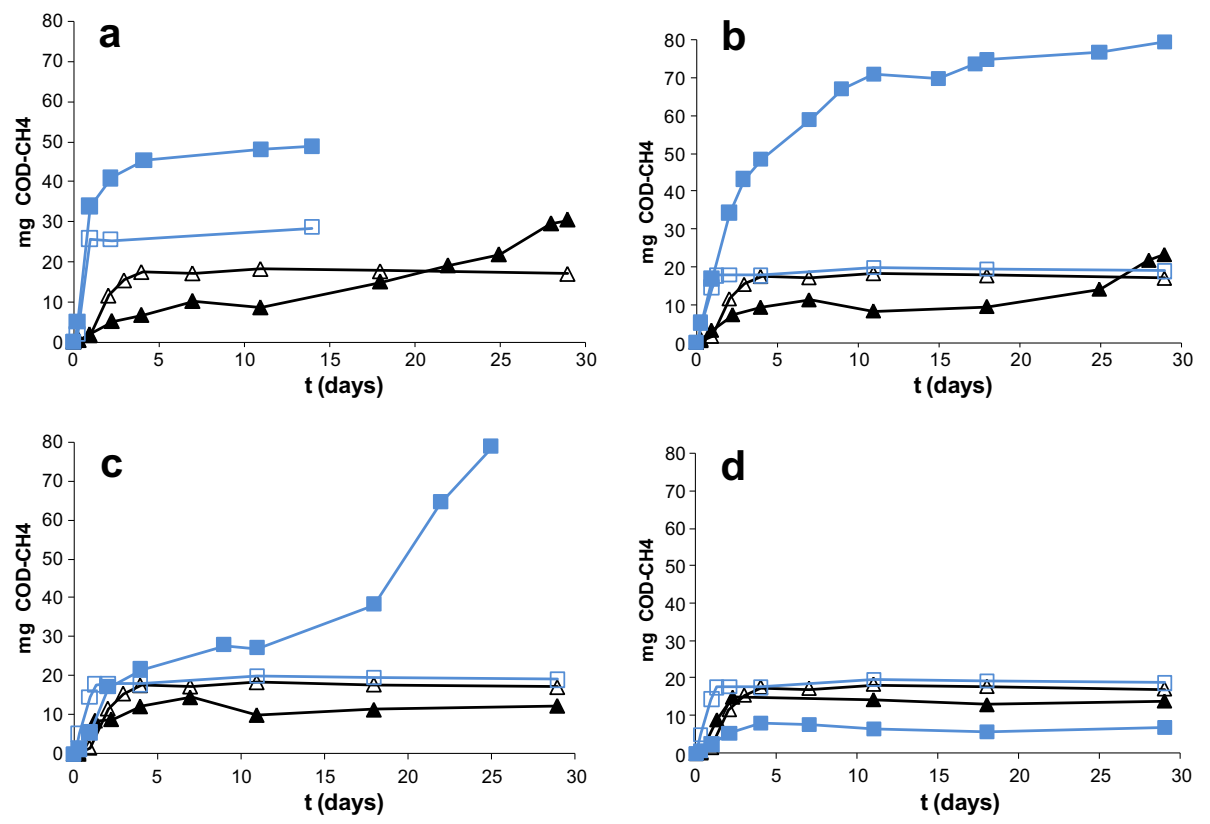

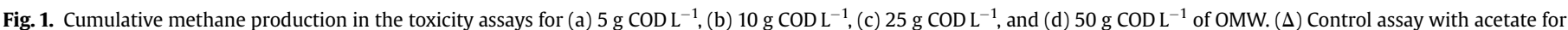

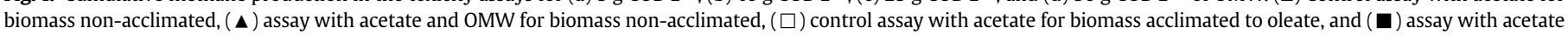
and OMW for biomass acclimated to oleate. 

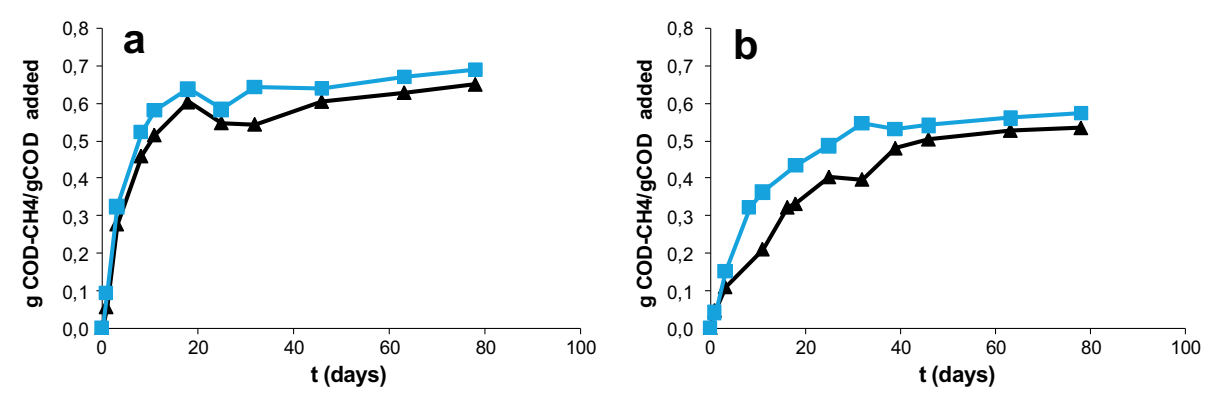

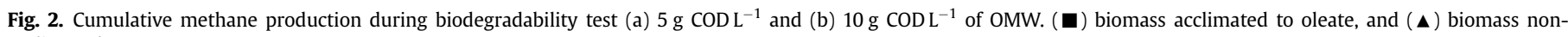
acclimated.

performed in duplicate and were incubated at $37^{\circ} \mathrm{C}$ and $150 \mathrm{rpm}$. The methane accumulated in the vessels' headspace was measured by gas chromatography, as described in the analytical methods section, by collecting $500 \mathrm{uL}$ of sample volume using a gas-tight syringe. Methane production was corrected for standard temperature and pressure (STP) conditions.

In the toxicity experiments, the amount of methane produced was converted to its $\mathrm{COD}$ equivalent $\left(\mathrm{g} \mathrm{COD}-\mathrm{CH}_{4}\right)$ considering the biochemical methane potential ( $350 \mathrm{~L} \mathrm{CH}_{4} / \mathrm{kg} \mathrm{COD).} \mathrm{In} \mathrm{the} \mathrm{biode-}$ gradability experiments the methane yield was expressed as the ratio between COD-methane produced and the COD added to the batch vials (g COD- $\mathrm{CH}_{4} / \mathrm{g}$ COD added).

\subsection{Analytical methods}

Total chemical oxygen demand (COD) was determined using test kits (Hach Lange). Total and volatile solids (TS and VS) were determined according to Standard Methods [22]. Total phenols were evaluated by a modified Folin-Ciocalteau method [23]. Methane was analysed in a gas chromatograph (Chrompack 9000) equipped with a flame ionisation detector and a $2 \mathrm{~m} \times 1 / 8^{\prime \prime}$ Chromosorb 101 (80-120 mesh) column. Nitrogen was used as carrier gas $\left(30 \mathrm{~mL} \mathrm{~min}^{-1}\right)$. The temperature of the column, injector and detector were 35,110 , and $220^{\circ} \mathrm{C}$, respectively.

\section{Results and discussion}

Olive mill wastewater toxicity toward acetoclastic bacteria was evaluated for two different sludges: BAO and BNA. The results are shown in Fig. 1.

In the toxicity tests performed with BAO, the addition of 5 and $10 \mathrm{~g} \mathrm{COD} \mathrm{L}^{-1}$ of OMW to the batch vials, did not cause any inhibition since the initial methane production rates were similar to the control assay (Fig. 1a and b). Indeed, at these OMW concentrations both acetate and OMW were consumed in the first days. However, at $25 \mathrm{~g} \mathrm{COD} \mathrm{L}^{-1}$ of OMW the initial methane production rate was slower than the assay only with acetate (Fig. 1c). At this OMW concentration, acetate and OMW degradation followed diauxic behaviour. According to Alves et al. [24] the methane production attained in the first stage could be correlated with the fixed acetate concentration added to the vial. The second stage of methane production corresponds to the OMW degradation. When $50 \mathrm{~g}$ $\mathrm{COD} \mathrm{L}^{-1}$ of OMW were added to the batch vials the acetate was not all consumed even after 28 days suggesting an inhibition of the BAO (Fig. 1d).

In the toxicity experiments carried out with BNA, an inhibitory effect occurred for all the OMW concentrations tested. At 5 and $10 \mathrm{~g}$ $\mathrm{COD} \mathrm{L}^{-1}$ of OMW, the equivalent methane production to the acetate added to the vials was only achieved after 20 and 27 days, respectively (Fig. 1a and b). At 25 and $50 \mathrm{~g} \mathrm{COD} \mathrm{L}^{-1}$ of OMW, the final methane production was lower than the control assay (Fig. 1c and d).

The results obtained with the BNA clearly indicate a toxic effect of OMW toward the acetoclastic activity for all the concentrations studied. In contrast, the results obtained with the BAO showed resistance to OMW at 5 and $10 \mathrm{~g} \mathrm{COD} \mathrm{L}^{-1}$. Even at $25 \mathrm{~g} \mathrm{COD} \mathrm{L}^{-1}$, both substrates were degraded. The toxicity of OMW has been attributed to lipids and phenolic compounds [20]. However, in this case, the results obtained suggest that an adapted consortium to lipids prevents the bacterial inhibition (between 5 and $10 \mathrm{~g} \mathrm{COD} \mathrm{L}^{-1}$ of OMW). Consequently, OMW is easily converted to biogas, enhancing the overall methane production. Nevertheless, high concentrations of olive mill effluent may lead to the increase of toxicity induced by the phenolic compounds.

Biodegradability batch experiments were performed in order to compare the cumulative methane production patterns when OMW was biodegraded with BAO and BNA (Fig. 2). No lag-phases were observed for the concentrations studied. Although, a similar behaviour was observed for the two different sludges, the biodegradation rate of OMW was higher in batch vials with acclimated sludge. In fact, the biodegradation rates of OMW in BAO were 3.56 and $3.89 \mathrm{mg} \mathrm{COD}-\mathrm{CH}_{4} \mathrm{~d}^{-1}$ and in the BNA were 3.30 and $2.04 \mathrm{mg}$ COD- $\mathrm{CH}_{4} \mathrm{~d}^{-1}$, for 5 and $10 \mathrm{~g} \mathrm{COD} \mathrm{L}^{-1}$, respectively.

At the end of the experiment (after 78 days) $49-56 \%$ of biodegradation was reached. These values exclude the methane production determined in the blank assays (inoculum in the absence of substrate). Those assays showed residual methane production of 9.2 and $5.4 \mathrm{mg}$ COD-CH4/batch for BAO and BNA, respectively. COD was not completely removed mainly due to nonbiodegradable compounds like coloured polyphenolic compounds, which are present in this type of wastewaters. They accumulate in the sludge hindering the OMW biodegradation $[18,25]$. It is important to note that comparing both tests (toxicity and biodegradability) for the BNA, it was verified that an inhibition occurred when acetate was added as a co-substrate. This fact indicates that a substrate competition may lead to the process limitation.

This study demonstrates that the anaerobic digestion of a real wastewater with a high content of fat can be enhanced by using an adapted consortium to LCFA, since a higher resistance to OMW toxicity was achieved and the biodegradation rate was improved, enhancing the biogas production.

\section{Conclusion}

OMW is more easily converted to biogas by using an adapted consortium to lipids, enhancing the overall methane production. However, high concentrations of olive mill effluent (50 g $\mathrm{COD} \mathrm{L}^{-1}$ ) may lead to an increase in the toxicity that is probably induced by the phenolic compounds present in this kind of wastewater. 
The results suggest that the use of an acclimated sludge to LCFA compounds is a promising approach to accelerate the anaerobic digestion start-up of the OMW and to reduce the operational problems caused by the inhibitory compounds. This finding could be useful to overcome the issue of having huge quantities of wastewater in short periods (olive oil campaign lasts 3-4 months per year) combined with the fact that anaerobic digestion has long periods of start-up and process stabilisation.

\section{Acknowledgements}

The authors acknowledge the financial support of the "Fundação para a Ciência e a Tecnologia", FCT/MCTES, through the project PTDC/ENR/69755/2006 and also through the grant given to Marta Gonçalves SFRH/BD/40746/2007. The authors also thank Cristiana Gonçalves for the supply of OMW sample and help in the characterization experiments.

\section{References}

[1] Kapellakis I, Tsagarakis $\mathrm{K}$, Crowther J. Olive oil history, production and byproduct management. Reviews in Environmental Science and Biotechnology 2008;7(1):1-26.

[2] Sobhi B, Isam S, Ahmad Y, Jacob $\mathrm{H}$. Reducing the environmental impact of olive mill wastewater in Jordan, Palestine and Israel. In: Hillel S, Hassan D, editors. Israel-Palestinian water issues-from conflict to cooperation. Berlin Heidelberg, Germany: Springer; 2007.

[3] Azbar N, Yram A, Filibeli A, Muezzinoglu A, Sengul F, Ozer A. A review of waste management options in olive oil production. Critical Reviews in Environmental Science and Technology 2004;34:209-47.

[4] Rozzi A, Malpei F. Treatment and disposal of olive mill effluents. International Biodeterioration and Biodegradation 1996;38:135-44.

[5] Arvanitoyannis I, Kassaveti A, Stefanatos S. Olive oil waste treatment: a comparative and critical presentation of methods, advantages \& disadvantages. Critical Reviews in Food Science and Nutrition 2007;47(3):187-229.

[6] Munster M, Lund $H$. Use of waste for heat, electricity and transport challenges when performing energy system analysis. Energy 2009;34:636-44

[7] Murphy J, McKeogh E. The benefits of integrated treatment of wastes for the production of energy. Energy 2006;31:294-310.

[8] Marques IP. Anaerobic digestion treatment of olive mill wastewater for effluent re-use in irrigation. Desalination 2001;137:233-9.
[9] Show K-Y, Wang Y, Foong S-F, Tay J-H. Accelerated start-up and enhanced granulation in up-flow anaerobic sludge blanket reactors. Water Research 2004;38:2293-304.

[10] Michaud S, Bernet N, Buffière P, Roustan M, Moletta R. Methane yield as a monitoring parameter for the start-up of anaerobic fixed film reactors. Water Research 2002;36:1385-91.

[11] Percheron G, Bernet N, Moletta R. Start-up of anaerobic digestion of sulfate wastewater. Bioresource Technology 1997;61:21-7.

[12] Mustapha S, Ashhuby B, Rashid M, Azni I. Start-up strategy of a thermophilic upflow anaerobic filter for treating palm oil mill effluent. Transactions IChemE 2003;81:262-6.

[13] Puñal A, Trevisan M, Rozzi A, Lema J. Influence of $C: N$ ratio on the start-up of up-flow anaerobic filter reactors. Water Research 2000;34(9):2614-9.

[14] Yacob S, Shirai Y, Hassan M, Wakisaka M, Subash S. Start-up operation of semi-commercial closed anaerobic digester for palm oil mill effluent treatment. Process Biochemistry 2006;41:962-4.

[15] Fiestas Ros de Ursinos J, Gamero R, Cabello R, Buendia A, Jauregui G. Anaerobic depollution of olive oil mill effluents as source of energy. Grasas y Aceites 1982;33:265-70.

[16] Azbar N, Tutuk F, Keskin T. Biodegradation performance of an anaerobic hybrid reactor treating olive mill effluent under various organic loading rates. International Biodeterioration and Biodegradation 2009;63(6):690-8.

[17] Boari G, Brunetti A, Passino R, Rozzi A. Anaerobic digestion of olive oil mill wastewaters. Agricultural Wastes 1984;10:161-75.

[18] Hamdi M. Toxicity and biodegradability of olive mill wastewaters in batch anaerobic digestion. Applied Biochemistry and Biotechnology 1992;37: 155-63.

[19] Jeganathan J, Nakhla G, Bassi A. Long-term performance of high-rate anaerobic reactors for the treatment of oily wastewater. Environmental Science and Technology 2006;40(20):6466-72.

[20] Beccari M, Carucci G, Majone M, Torrisi L. Role of lipids and phenolic compounds in the anaerobic treatment of olive oil mill effluents. Environmental Technology 1999;20(1):105-10.

[21] Cavaleiro AJ, Salvador AF, Alves JI, Alves M. Continuous high rate anaerobic treatment of oleic acid based wastewater is possible after a step feeding start-up. Environmental Science and Technology 2009;43(8):2931-6.

[22] APHA-American Public Health Association. Standard methods for the examination of water and wastewater. 20th ed. Washington, DC: American Public Health Association; 1998.

[23] Singleton VL, Rossi Jr JA. Colorimetry of total phenolics with phosphomolybdic-phosphotungstic acid reagents. American Journal of Enology and Viticulture 1965;16:144-58.

[24] Alves MM, Vieira JAM, Pereira RMA, Pereira MA, Mota M. Effects of lipids and oleic acid on biomass development in anaerobic fixed-bed reactors part II: oleic acid toxicity and biodegradability. Water Research 2001;35(1):264-70.

[25] Field J, Lettinga G, Geurts M. The methanogenic toxicity and anaerobic degradability of a hydrolyzable tannin. Water Research 1987;21:367-74. 